This PDF is a selection from an out-of-print volume from the National Bureau of Economic Research

Volume Title: Regionalism and Rivalry: Japan and the United States in Pacific Asia

Volume Author/Editor: Jeffrey Frankel and Miles Kahler, editors

Volume Publisher: The University of Chicago Press

Volume ISBN: 0-226-25999-4

Volume URL: http://www.nber.org/books/fran93-1

Conference Date: April 2-5, 1992

Publication Date: January 1993

Chapter Title: Pricing Strategies and Trading Blocs in East Asia

Chapter Author: Gary R. Saxonhouse

Chapter URL: http://www.nber.org/chapters/c7835

Chapter pages in book: (p. 89 - 124) 


\title{
Pricing Strategies and Trading Blocs in East Asia
}

\author{
Gary R. Saxonhouse
}

\subsection{Introduction}

From the mid-eighteenth century until the First World War, the scale of political units around the world grew ever larger. At least part of the motivation for large political size during these years was economic. The past few years have seen an increasingly rapid unraveling of this process. Looking at the European Community (EC), the North American Free Trade Agreement (NAFTA), and even the Asia Pacific Economic Cooperation (APEC), it's hard not to think of strong, regional customs unions as the wave of everyone's future. Yet the experience of the Soviet Union, Yugoslavia, and Czechoslovakia really does suggest otherwise. The GATT-governed multilateral trading system has made possible the extraordinary economic success of microstates like Hong Kong and Singapore. And it is this success that has surely emboldened Estonians, Slovaks, and Tadjiks to assume that separation from large political units need not mean economic disaster. The great continental superpowers that came into existence before 1914 and that ran roughshod over cultural diversity may well have been made anachronistic not so much by increasing ethnic identification as by the open, multilateral global trading system of the late twentieth century. The multilateral trading system has been capable of providing a substitute for much of the special economic advantages of large political size. The door is now potentially open for a plethora of economically viable microstates organized, following East Asia, on the basis of cultural affinity.

The aspirations of regional economic arrangements do collide with the multilateral system. Slovaks may seek political independence, confident that the GATT will guarantee markets for their products even as it protects their access to vital imports. When Slovaks, however, attempt to negotiate the terms

Gary R. Saxonhouse is professor of economics at the University of Michigan. 
of their access to the European Community, they may be in for a nasty surprise. Of course, it is the new vitality of regional arrangements such as the European Community and NAFTA, and not the obsolescence of dinosaurs like the Soviet Union and Yugoslavia, that provides the context for this paper.

In the first section of this paper, the consequences of trading bloc formation for countries left outside such blocs will be reviewed. In particular, the case where the formation of such a bloc will leave outsiders worse off will be highlighted. This can happen even without the trading bloc violating Article 24 of the GATT. Still worse, such blocs can make insiders better off than in the case of global free trade. In this circumstance, insiders may have no incentive to let in additional members, except where the formation of a rival bloc is threatened. The formation of a regional trading bloc may not be a way station on the road to global free trade.

The case outlined in the first section of this paper reflects the concerns of the East Asian economies. Trading blocs are being formed elsewhere in the world. Even without violating existing GATT provisions, such blocs can lower East Asian welfare. These trading blocs may have no incentive to expand their membership to include East Asian economies except insofar as they fear provoking the formation of an East Asian trading bloc.

The second section of this paper reviews the prospects for a regional trade regime in East Asia. Intra-East Asian trade is currently not large by historical standards. Nor does the rapid growth in intra-East Asian trade reflect much more than the very rapid overall economic growth in this region relative to the rest of the world. Estimation of a bilateral model of intraindustry trade using a factor-endowment-based version of the gravity model suggests no East Asian bias in the trading patterns of the leading economies there. There is no evidence as yet that a rival trading bloc is being formed in East Asia in response to developments in Europe and North America.

In the final section of this paper, the exchange rate-induced pricing strategies of East Asian firms across East Asian markets are examined. The results suggest that country-specific pricing strategies seem characteristic of East Asian markets. Commodity arbitrage may be more difficult in East Asia than elsewhere. Despite considerable progress in trade liberalization by many of the East Asian economies over the past two decades, there is some indication that regionwide liberalization could still be of considerable benefit.

\subsection{The International Economic System and New Trading Blocs}

Since 1945 international trade theory has developed to the extent that it is now well understood that the formation of a regional trading bloc may be detrimental to the international economic system (Machlup 1977). It is possible that the benefits for members of a trading bloc through trade creation may be less than the costs imposed on nonmembers through trade diversion (Viner 1950). Indeed, shifts in the terms of trade in favor of members at the expense 
of nonmembers are responsible for many of the benefits that follow the organization of a trading bloc. This can happen even if a trading bloc leaves its protective barriers against nonmembers unchanged. Of course, matters can get worse. A newly formed bloc may succumb to temptation and attempt to exploit its newfound market power by raising its barriers against nonmembers and still further improving its terms of trade. Even without assuming such GATTinconsistent behavior, provided not all countries belong to trading blocs, trading blocs may be able, not just to improve member welfare, but to push it beyond what might be expected with global free trade.

By way of illustration consider a world with $N$ countries of equal size (see Krugman 1991). Each country is specialized in the production of a single good that is an imperfect substitute for the products of all other countries. These countries are not only equal in size; they also have identical preferences and produce their goods with the same technology. Each country imposes identical tariffs on the imports of all other countries, except trading bloc member countries impose no tariffs on the products of fellow members. While Krugman puts each of his symmetric countries in one of a number of equal-sized trading blocs and assumes that each country produces the same number of units of its single good, here it will be assumed that the global economy is divided up between members and nonmembers of a single bloc and that each country's production of its single good is variable.

Analysis of such a simple system cannot explain why a particular group of countries join together in any particular trading bloc. It can illuminate, however, what happens to member welfare, nonmember welfare, and global welfare when a single trading bloc is first organized and then grows in size. Analysis of a global economy made up of countries of equal size with virtually identical characteristics may seem remote from the substance of trade policy, but as will be seen, it does appear to capture the concerns of many of the East Asian economies.

Let

$$
X_{k i}=x_{k i} P_{k},
$$

where $X_{k i} \equiv$ value of exports from country $k$ to country $i ; x_{k i} \equiv$ volume of exports from country $k$ to country $i$; and $P_{k} \equiv$ price of country $k$ 's production.

The demand for country $k$ 's product by country $i$ is given by

$$
X_{k i}=\frac{Y_{i}}{N}-\frac{\beta}{N^{2}}\left[P_{k}\left(1+t_{k i}\right)-\frac{1}{N} \sum_{g} P_{g}\left(1+t_{g i}\right)\right],
$$

where $N \equiv$ number of countries; $Y_{i} \equiv$ country $i$ 's income; and $t_{k i} \equiv$ tariff imposed by country $i$ on country $k$ 's product.

Equation (2) states that country $i$ 's income will be spent equally on each country's products except to the extent that the prices of a country's product diverge from the average price level of all commodities. As noted above, the same demand relationship governs the behavior of each of the $N$ countries. In 
consequence, $\beta$ has no subscript. Where countries belong to the same trading bloc, $t_{k i}=0$; where countries do not, $t_{k i}=t$. Except between bloc and nonbloc members, the $N$ countries do not discriminate among their trading partners.

The demand for country $k$ 's product by country $i$ is met by country $k$ 's supply. The supply of country $k$ 's production is given by

$$
\pi_{k o}=\frac{\bar{\alpha}}{N}-\alpha \sum \frac{P_{g}\left(1+t_{g k}\right)}{N^{2} P_{k}},
$$

where $\pi_{k o} \equiv$ production of country $k$. Equation (3) is a standard supply function. Country $k$ 's production of its single product is a positive function of its price and a negative function of its costs. Since country $k$ produces a single good, all intermediate inputs must be imported from abroad.

If the impact of the formation and growth of trading blocs on individual country welfare and global welfare is to be assessed, it is helpful to discuss the determinants of gross global product $\pi_{o o}$, and $y_{k}$, country $k$ 's real income. From equation (3) and summing over $k$, the expression for gross global product is

$$
\pi_{o o}=\bar{\alpha}-\frac{\alpha}{N^{2}} \sum_{k} \sum_{g} \frac{P_{g}\left(1+t_{g k}\right)}{P_{k}} .
$$

Multiplying country $k$ 's production from equation (3) by real prices, real income for country $k$ is given by

$$
y_{k}=\frac{\pi_{k o} P_{k}}{\sum_{g} P_{g}}=\frac{\bar{\alpha} P_{k}}{\sum_{g} P_{g}}-\alpha \frac{\sum P_{g}\left(1+t_{g k}\right)}{N \sum P_{g}} .
$$

Equations (4) and (5) are expressions for gross global product and real income for country $k$ in terms of prices. The analysis here requires that gross global product and real income for country $k$ be evaluated as a function of bloc size and levels of protection. To do this, the system defined by equations (1), (2), and (3) must be solved for the determinants of these prices, and the resulting expression substituted back into equations (4) and (5).

Assuming that markets clear, the system defined by equations (1), (2), and (3) will be in equilibrium when nominal gross global product

$$
\pi_{o o}=\left[\bar{\alpha}+\beta\left(1+t_{k}\right)\right] P_{k}-\frac{1}{N} \sum_{g} P_{g}\left[\alpha\left(1+t_{g k}\right)+\beta\left(1+t_{g}\right)\right],
$$

where

$$
t_{k}=\frac{1}{N} \sum_{i}\left(1+t_{k i}\right)
$$

and

$$
\pi_{o o}=\sum_{i} Y_{i}
$$

Because countries in this system have the same size with identical preferences and technology, beyond their complete product differentiation they differ only 
to the extent that they are in or out of the trading bloc. In consequence, the only prices in this system will be the price of goods produced by trading bloc members and the price of goods produced by nonmembers. From equations (6), (7), and ( 8 ) the ratio of these prices can be obtained by

$$
\frac{P_{o}}{P_{b}}=\sigma=\frac{\bar{\alpha}+\beta\left(1+\frac{m}{N} t\right)+\alpha \frac{n}{N} t}{\bar{\alpha}+\beta\left(1+\frac{N-1}{N} t\right)+\alpha \frac{t}{N}}=1-\varphi
$$

where $P_{b} \equiv$ price of good produced by trading bloc; $P_{o} \equiv$ price of good produced outside of trading bloc; $n \equiv$ number of trading bloc members; and $m \equiv$ number of outsiders; and where

$$
\varphi=\frac{n-1}{N} \frac{\beta-\alpha}{\bar{\alpha}+\beta} t
$$

This price information can be substituted into gross global product equation (4) such that

$$
\begin{aligned}
\pi_{o o} & =\bar{\alpha}-\frac{\alpha}{N^{2}}\left[n^{2}+m n(1+t)\left(1-\varphi+\frac{1}{1-\varphi}\right)\right. \\
& +m(m-1)(1+t)+m] .
\end{aligned}
$$

The price information from equation (9) can also be substituted into equation (5) to yield expressions for the national income of both bloc members and nonmembers:

$$
y_{b}=\left[\bar{\alpha}-\frac{\alpha}{N}(N+m t-m \varphi)-m \varphi t\right] /(N-m \varphi),
$$

and

$$
\begin{aligned}
y_{o} & =\left\{\bar{\alpha}(1-\varphi)-\frac{\alpha}{N}(1+t)(1-\varphi)\left[\frac{n}{(1-\varphi)}+(m-1)(1-\varphi)\right.\right. \\
& \left.\left.+\left(\frac{1-\varphi}{1+t}\right)\right]\right\} /(N-m \varphi)
\end{aligned}
$$

With equations (11), (12), and (13) it's possible to examine what happens to gross global product and its distribution between bloc members and nonmembers as the bloc grows in size. In figure 3.1 the gross global product equation (11) is evaluated for different bloc sizes and for different levels of protection. Gross global product $\pi_{o o}$ is measured along the $y$-axis, while bloc size varies from one to thirty and tariff levels move from 0 to 150 percent. Clearly, in this simple world the creation and growth of a trading bloc is not detrimental to global welfare. As can be seen from figure 3.1, at any given level of $t$ as $n$ increases from 1 to $30, \pi_{o o}$ increases in value. That is to say, at any given level 


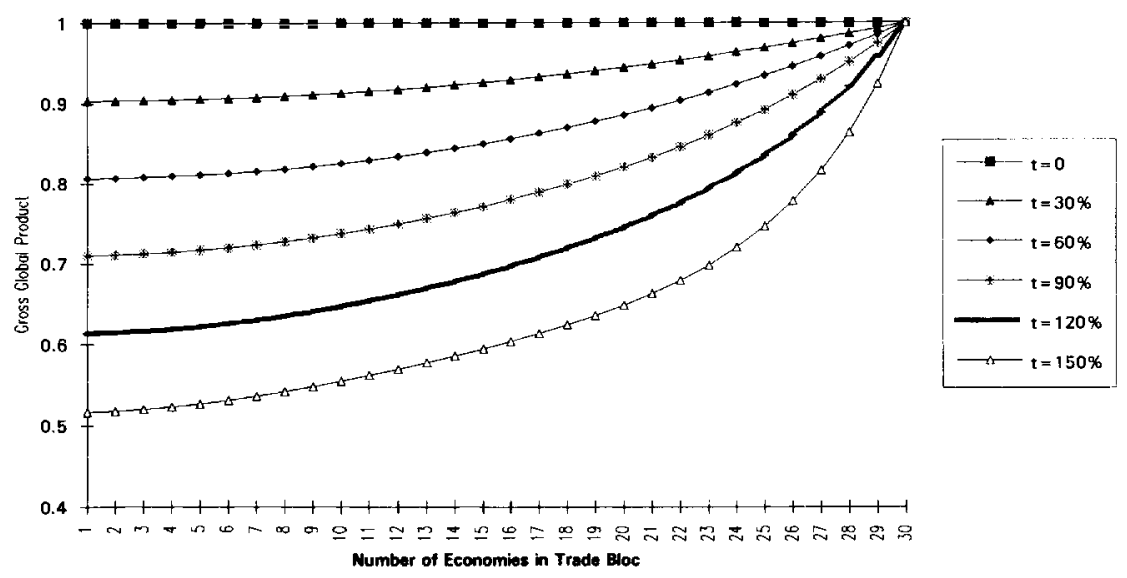

Fig. 3.1 Gross global product and trading bloc size

Note: $t=$ tariff rate.

of protection the larger the bloc, the greater the gross global product. In this world, with every expansion of the size of the trading bloc, trade creation dominates trade diversion. ${ }^{1}$ Of course, a bloc that includes all countries is global free trade, the equivalent of $t=0$, which is the best situation of all.

At the same time that for any given level of protection an increase in the size of a trading bloc will increase gross global product, for any given size of trading bloc an increase in protection will diminish it. As can be seen from figure 3.1, for any given $\mathrm{n}$, an increase in $\mathrm{t}$ will diminish $\pi_{o o}$. In this world a trading bloc that complies with Article 24 of the GATT cannot damage global welfare. A trading bloc that as it increases in size, however, takes full advantage of its increased market power to increase its barriers can do considerable damage. From figure 3.1 the trade-offs between the benefits to gross global product of a bigger trading bloc and the risks to it from increased protection are apparent.

The gain in gross global product that comes from a larger trading bloc when protection against outsiders is held constant will not be shared equally between members and nonmembers. As seen from equations (10)-(13), the distribution

1. Because all the countries in this model are alike except for the complete differentiation of their products, and because output is not fixed, the expansion of the size of a trading bloc does not lead to a decline in global welfare. In Viner (1950), trade diversion can outpace trade creation because links between natural trading partners can be severed by the creation of a customs union. Here there are no natural trading partners because all countries are alike or otherwise they are symmetrically different. As figure 3.1 indicates, gross global product accelerates in proportion to the number of tariff walls eliminated. The results here differ not only from Viner but also from Krugman (1991). In Krugman, even with countries that are virtually identical except for complete product differentiation, the relationship between bloc size and global welfare is not monotonic. Kugman's results depend critically on having each country's output fixed and having all countries being members of some equal-sized bloc. In this paper, by contrast, country output is variable, and there is only one bloc. If a country does not belong to this bloc, all its exports must bear a tariff $t$. 
of gains between members and nonmembers will depend critically on the relative values of $\alpha$ and $\beta$. For example, when $\alpha$, the supply parameter, is just equal to $\beta$, the demand parameter, the entire gain in global product will go to bloc members and the real income of nonmembers will stay constant unless they join the bloc.

With full employment of resources, however, it is likely that $\beta$ will be considerably larger than $\alpha$. This is the situation that's analyzed in figures 3.2 and 3.3 , the counterparts to figure 3.1. In figures 3.2 and 3.3 the nonmember national income equation (13) and the bloc member national income equation (12) are evaluated for different trading bloc sizes and for different levels of protection. National income is in each case measured along the $y$-axis, while bloc size once again varies from 1 to 30 and tariff levels move from 0 to 150 percent.

As seen from figure 3.2 , in the case where the demand parameter substantially exceeds the supply parameter, countries remaining outside the trading bloc don't just lose out relatively. National income actually declines for any given level of protection as the trading bloc increases in size. As is apparent from equations (9) and (10), this result reflects the continuous decline of nonbloc member producer prices relative to member producer prices. As the trading bloc increases in size, more and more of what nonmembers want to buy becomes increasingly more expensive in terms of what they produce. Under such conditions, the nonmember incentives to join the trading bloc are overwhelming. This incentive becomes ever stronger even though the bloc, by leaving the level of $t$ constant, does not violate Article 24. From figure 3.1 it is also clear that if bloc members and nonmembers can mutually agree to lower $t$, nonmembers can be easily compensated for the loss in national income they suffer as the trading bloc grows.

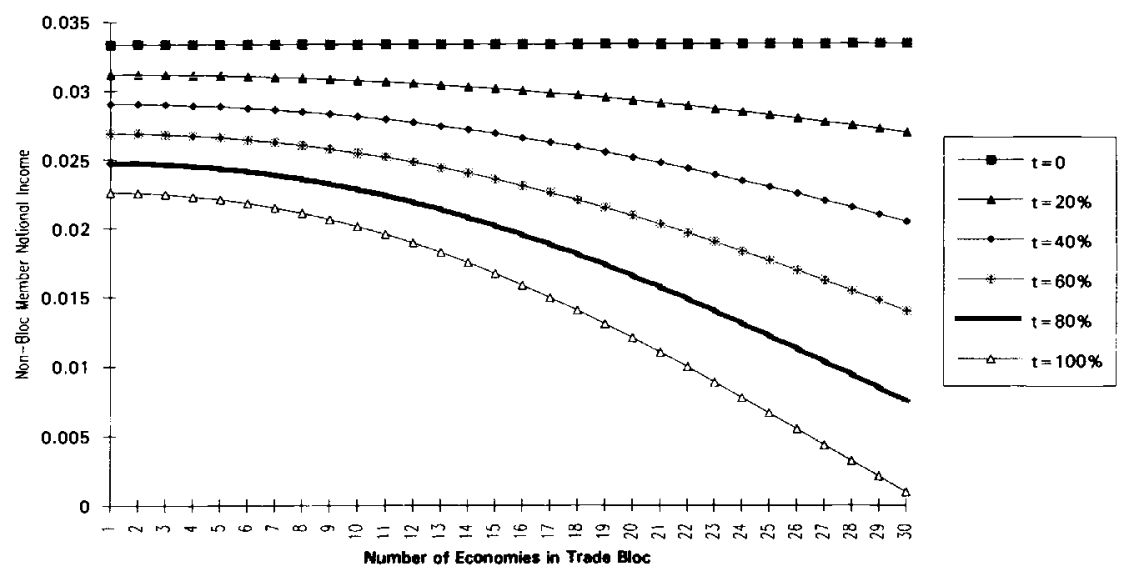

Fig. 3.2 Non-bloc member national income and trading bloc size Note: $t=$ tariff rate. 


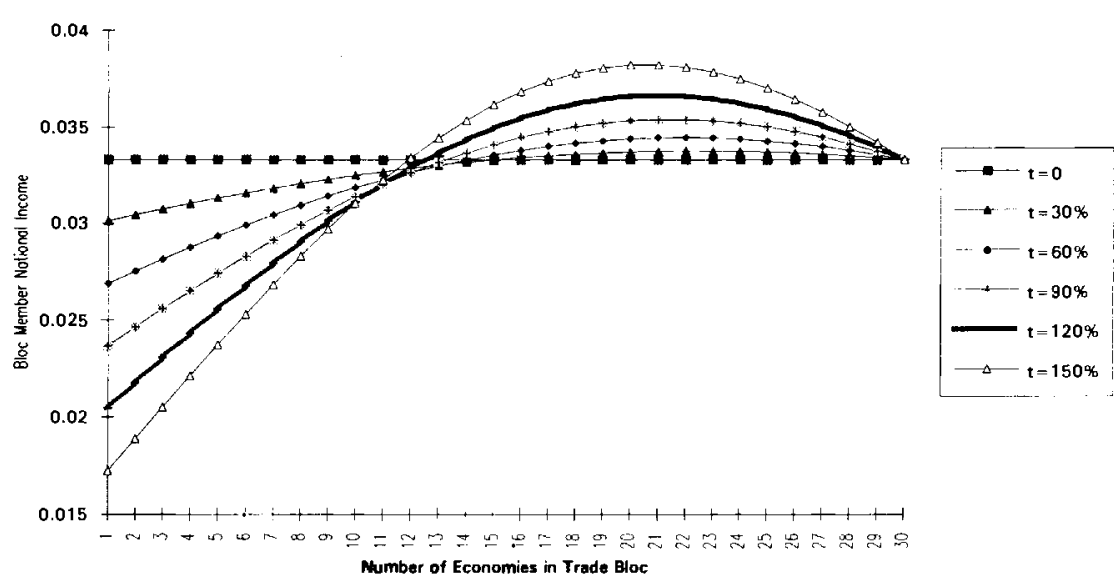

Fig. 3.3 Bloc member national income and trading bloc size Note: $t=$ tariff rate.

While the national income of each nonmember declines monotonically, as seen from figure 3.3, trading bloc member national income increases as the trading bloc grows in size from its very first members. A larger trading bloc means members can buy more products without trade restrictions, and it means, as noted earlier, increasingly favorable terms of trade with nonmembers. As long as admitting new members to the trading bloc increases the national income of each bloc member, the bloc has no incentive to be exclusive. As is apparent in figure 3.3, after the trading bloc has approximately twenty out of a possible thirty members (Europe and North America?), the incentive to admit additional members (East Asia?) and move on to free trading evaporates. At this point, the benefits to trading bloc members from being able to buy additional products without trade restrictions becomes less than the losses suffered from having fewer countries outside the trading bloc trading with members on unfavorable terms. With further expansion of the trading bloc, the national income of each trading bloc member declines monotonically as each new member joins, up to and including the point when no one is left outside and global free trade is achieved. Members of a trading bloc can achieve real income above what they would receive under free trade if they agree to keep their bloc exclusive. They certainly have no incentive to admit new members on a symmetric basis. ${ }^{2}$ This important result will hold only so long as outsiders don't organize themselves into a competitive trading bloc. ${ }^{3}$

2. See Kemp and Wan (1976, 95-97). Since global free trade maximizes global welfare, there will always be some system of side payments that will allow nonmembers to bribe members into allowing them entry to the trading bloc. The terms of such side payments leaving symmetric economies in vastly different circumstances may make this an unappealing alternative.

3. The structure of the game that might result in this event is analyzed empirically in Stoeckel, Pearce, and Banks (1990), among other places. 
Once again, nothing in the preceding analysis assumes that the trading bloc will attempt to exploit the growing market power that comes with increasing size and raise its barriers against nonmembers. Trading bloc members can achieve real income levels better than global free trade, and nonmembers can face continuous declines in real income as the trading bloc expands its membership, even while the trading bloc behaves consistently with GATT Article 24 and makes no attempt to exploit its increasing market power.

\subsection{The East Asian Trade Regime}

The case just outlined captures many of the concerns of the economies on the Pacific Rim of Asia. Very comprehensive regional trading arrangements have been organized or have been greatly strengthened in North America and in Europe. The possibility that, even without raising new barriers at all, the growing role of such blocs in the global economy could lower East Asian welfare is very real. The proliferation of voluntary export restraints, orderly marketing agreements, local content rules, new dumping regulations, and other aggressive unilateral measures against some of these economies suggests it may even be naive to assume that such trading blocs are the necessary way stations to a newly invigorated global trading system. The optimum size of such blocs, from the existing members' point of view, makes it naive to assume that as a matter of course they will be nonexclusive. It may not make sense to continuously expand the size of such trading blocs. In particular, it's not hard to imagine some or all East Asian economies being excluded from European or Western Hemispheric regional trading arrangements.

Exclusive arrangements will be preferred to global free trade by members of regional trading blocs only so long as there remain a nontrivial number of nonmembers who retain protective barriers against each other as well as against the trading bloc itself. If nonmembers organize their own rival trading bloc, free trade may once again become a superior outcome for all concerned. It is with this perspective that the prospect of new trading arrangements in East Asia should be examined. While no formal trading bloc has as yet arisen in East Asia, do emerging trading patterns there suggest that this is happening implicitly? In particular, do intraregional trading patterns suggest a Japancentered rival to the European Community and NAFTA is being created? Is the scenario suggested by the trade theory in section 3.2 coming to pass?

At present, intraregional trade is approximately 40 percent of all East Asian trade. This is modest by comparison with Western Europe, where intraregional trade is over 70 percent of total trade, but it's considerably larger than the role played by intraregional trade in North America. Not only is intraregional trade more important in East Asia than in North America, its relative importance has been growing rapidly. Twenty years ago intraregional trade was no more than 30 percent of East Asian trade. By marked contrast, intraregional trade in North America has actually been declining over the past twenty years. Interest- 
ingly, if North America, East Asia, Australia, and New Zealand are combined into a single region, the share of intraregional trade in the total trade of the Pacific grouping approaches Western European levels. And over the past two decades, as over the past decade, intra-Pacific trade has been growing more rapidly than intra-Western European trade.

These intraregional trade trends provide some perspective on East Asia's position in a possibly regionalizing global economy. Regional trade is becoming more important for East Asia. This need not reflect increasing isolation at all. Trade with East Asia is not only increasingly important for the East Asian economies themselves. It's also increasingly important for North America and for Europe. The increasing bias toward East Asia itself in East Asian trade might reflect a nascent trading bloc, or since East Asian trade is also increasingly more important for North America and for Europe, it may reflect no more than the increasing economic weight of East Asia in the global economy.

Since there is no reason to expect one country's trade to be proportionally distributed to all other countries, the issue of whether there is regional bias in East Asia trade really needs to be addressed systematically by estimating a model of bilateral trade. The model that will be used to make such estimates can explain both cross-country and cross-commodity net and gross trade by making allowances for economies of scale and monopolistic competition, as well as for the more familiar differences in natural resources, capital, skills, and other national endowments. ${ }^{4}$

\subsubsection{Factor-Endowment-Based Gravity Equations}

Assume that all manufactured goods are differentiated by country of origin. Given the same homothetic preferences usually assumed in empirical work making use of Heckscher-Ohlin-style trade models, each economy will consume identical proportions of each good (Leamer 1984). This means that country $k$ 's export of good $j$ to country $i$ will be given by

$$
x_{k i}^{j}=S_{i} \pi_{k o}^{j}
$$

where $x_{k i}^{j} \equiv$ export of variety $k$ of good $j$ to country $i, \pi_{k o}^{j} \equiv$ production of good $j$ in country $k, \pi_{k o} \equiv \sum_{j} \pi_{k o}^{j} \equiv$ GNP of country $k, \pi_{o o} \equiv \sum_{i} \pi_{i o} \equiv \operatorname{global} G N P_{i}$, and $S_{i} \equiv \pi_{o o} / \pi \equiv$ share of country $i$ in global GNP. ${ }^{5}$

$$
S_{i}=\frac{\pi_{i o}}{\pi_{o o}}=\frac{\sum_{s} W_{s i} L_{s i}}{\sum_{k} \pi_{k o}}
$$

\footnotetext{
4. The model presented here is an extension to bilateral trade of earlier work presented in Saxonhouse (1989). See also Saxonhouse (1992).

5 . The properties of $\pi$, the GNP function, are described in more detail in Saxonhouse and Stern (1989).
} 
where $L_{s i} \equiv$ endowment of factor of production $s$ in economy $i$, and $W_{s i} \equiv$ rental for factor of production $s$ in economy $i$.

Following the approach taken in Heckscher-Ohlin comparative advantage analyses, if factor price equalization is assumed, then by Hotelling's lemma, if $\pi_{k o}$ is differentiated, ${ }^{6}$

$$
\pi_{k o}^{j}=\sum_{s=1}^{K} R_{j s} L_{s k}
$$

where $R_{j s}$ is a function of parameters of $\pi_{k o}$ and output prices, which are assumed to be constant.

Substituting equations (15) and (16) into equation (14), we get

$$
x_{k i}^{j}=\sum_{s=1}^{K} \sum_{r=1}^{K} B_{j s r} L_{s k} L_{r i}, \quad i=1, \ldots, N,
$$

where $B_{j s r}$ are functions of $\pi_{k o}^{j}$ and $\pi_{i o}$ and where output prices will be constant under the assumptions already made. Equation (17) is a factor-endowmentbased version of the gravity equation, which has been used for years as a framework for estimating bilateral trade relationships (Anderson 1979). Plausibly, it explains bilateral trade flows by the interaction between exporter and importer factor endowments. Alternatively, if equation (14) is divided by $\pi_{i o}$ before equations (15) and (16) are substituted into it, we get export shares as a simple linear function of exporter factor endowments:

$$
\frac{x_{k i}^{j}}{\pi_{i o}}=\sum_{s=1}^{K} B_{j s}^{*} L_{s k}, \quad i=1, \ldots, N .
$$

The structure embodied in equations (17) and (18) results from relaxing many of the strictest assumptions of the Heckscher-Ohlin model in order to incorporate hitherto neglected phenomena in a bilateral trade model. Still further relaxation is possible. Suppose that the assumption of strict factor price equalization across countries is dropped. Suppose, rather, that international trade equalizes factor prices only when factor units are normalized for differences in quality. For example, observed international differences in the compensation of ostensibly unskilled labor may be accounted for by differences in labor quality. Instead of equations (17) and (18) we get

$$
x_{k i}^{j}=\sum_{s=1}^{K} \sum_{r=1}^{K} B_{j s r} a_{s k} a_{r i} L_{s k} L_{r i}, \quad i=1, \ldots, N,
$$

and

6. The GNP function, $\pi$, has been defined to allow for differentiated products and economies of scale. This can be done by including optimal firm scale in $\pi$, following the approach taken by Helpman and Krugman (1985). Provided optimal firm scale is small relative to market size, change in industry output can be achieved by changes in the number of firms in the industry. Firms are assumed to be identical. This means that at the industry level there will be constant returns to scale.

7. This was first pointed out by Leontief (1956) as a possible explanation for the empirical failure of the simple Heckscher-Ohlin model. 


$$
\frac{x_{k i}^{j}}{\pi_{i o}}=\sum_{s=1}^{K} B_{j s r}^{*} a_{s k} L_{s k}
$$

where $a_{s k} \equiv$ quality of factors in country $k$.

\subsubsection{Estimation Procedures}

Equations $\left(17^{\prime}\right)$ and $\left(18^{\prime}\right)$ can be estimated for $N$ commodity groups and $K$ countries using cross-country data. For example, the terms $a_{s k}$ are not directly observable but can be estimated from equation (18'). Formally, the estimation of equation (18') with the $a_{s k}$ differing across countries and unknown is a multivariate, multiplicative errors-in-variables problem. Instrumental variable methods will allow consistent estimation of the $B_{j s r}^{*}$. For any given crosscountry sectoral equation, the $a_{s k}$ will not be identified. In particular, for the specification adopted in equation $\left(18^{\prime}\right)$, at any given time there are $N$ crosssections that contain the identical independent variables. This circumstance can be exploited to permit consistent estimation of the $a_{s k}{ }^{8}$ Since the same error will recur in equation after equation owing to the unobservable quality terms, it is possible to use this recurring error to obtain consistent estimates of the quality terms. These estimates of the $a_{s k}$ can then be used to adjust the factor-endowment data in equations $\left(17^{\prime}\right)$ and $\left(18^{\prime}\right)$ to obtain more efficient estimates of $B_{j s r}$ and $B_{j s r}^{*}{ }^{9}$

\subsubsection{Estimation of the Trade Model}

Equations $\left(17^{\prime}\right)$ and $\left(18^{\prime}\right)$ are estimated with data taken from the forty-two countries listed in table $3.1 .^{10}$ Equations $\left(17^{\prime}\right)$ and $\left(18^{\prime}\right)$ are estimated for each of the twenty-nine manufacturing sectors listed in table 3.2 for 1985 . The six factor endowments used in this estimation include directly productive capital, labor, educational attainment, petroleum reserves, arable land, and transport resources. ${ }^{\prime \prime}$ The Heckscher-Ohlin equations $\left(17^{\prime}\right)$ and $\left(18^{\prime}\right)$ are assumed to hold up to an additive stochastic term.

8. The approach taken here is analogous to the two-step "jackknife" procedure first proposed in Guilkey and Schmidt (1973). As an example of the approach taken here, let $a_{s k}=1+a_{s k}^{\prime}$, assuming $E\left(a_{s k}^{\prime}\right)=0$. Using instrumental variable techniques in the presence of multiplicative errors allows consistent estimates of the $B_{j s}^{*}$. Using these estimates, for each economy an $N(J-1) X 1$ vector $\left[v_{i}\right]$ of the net trade residuals can be formed. Consistent estimates of the quality terms can be obtained from

$$
\left(B_{j s r}^{*} L_{s k}\right)^{\prime}\left(B_{j s r}^{*} L_{s k}\right)^{-1}\left(B_{j s r}^{*} L_{s k}\right)^{\prime}\left(v_{j}\right)
$$

9. Following Durbin (1954), and in common with two-stage least squares, the approach taken here uses synthetic instrumental variables. Factor endowments are ordered according to size, and rank is used as an instrument.

10. Since the factor-endowment variables in equation (18) explain national development, there is no need to limit the sample used here to just the most advanced economies. In general, lessadvanced economies impose more protection than the most-advanced economies. This development-related protection is explained by changes in the levels of the factor endowments. Typically, the higher the level of factor endowments, the less the protection.

11. Following the suggestion of Dixit and Norman (1980), transport costs are incorporated in the Heckscher-Ohlin framework by treating them as another factor of production. Transport costs 
Table 3.1

Country Sample for Empirical Work

\begin{tabular}{lll}
\hline Argentina & Indonesia & Philippines \\
Australia & Ireland & Portugal \\
Austria & Italy & Singapore \\
Belgium & Jamaica & Spain \\
Brazil & Japan & Sri Lanka \\
Chile & Korea & Sweden \\
Denmark & Malaysia & Switzerland \\
Finland & Malta & Taiwan \\
France & Mexico & Thailand \\
Germany & Netherlands & Turkey \\
Greece & New Zealand & United Arab Republic \\
Honduras & Nigeria & United Kingdom \\
Hong Kong & Norway & United States \\
India & Peru & Yugoslavia \\
\hline
\end{tabular}

Table 3.2

Trade Sectors in Sample

\begin{tabular}{ll}
\hline ISIC\# & Sector \\
\hline 311 & Food manufacturing \\
312 & Other food manufacturing \\
313 & Beverage industries \\
314 & Tobacco manufactures \\
321 & Manufactures of textiles \\
322 & Manufactures of wearing apparel except footwear \\
323 & Manufactures of leather products except footwear and apparel \\
324 & Manufactures of footwear except rubber or plastic \\
331 & Manufactures of wood and cork products except furniture \\
332 & Manufactures of furniture and fixtures except primarily metal \\
341 & Manufactures of paper and paper products \\
342 & Printing, publishing, and allied industries \\
351 & Manufactures of industrial chemicals \\
352 & Manufactures of other chemical products \\
353 & Petroleum refineries \\
354 & Miscellaneous products of petroleum and coal \\
355 & Rubber products \\
356 & Plastic products not classified elsewhere \\
361 & Pottery, china, and earthenware \\
362 & Glass and glass products \\
369 & Other nonmetallic mineral products \\
371 & Iron and steel basic industries \\
372 & Nonferrous metal basic industries \\
381 & Fabricated metal products except machinery and equipment \\
382 & Manufactures of machinery except electrical \\
383 & Electrical machinery, apparatus, appliances, and supplies \\
384 & Transport equipment \\
385 & Professional and scientific measuring and control equipment \\
390 & Other manufacturing industries \\
\hline &
\end{tabular}


Table 3.3 The Estimation of $x_{k i}^{j}=\sum_{s=1}^{K} \sum_{r=1}^{K} B_{j s r} a_{s k} a_{r i} L_{s k} L_{r i}$

\begin{tabular}{lccccc}
\hline ISIC\# & $R^{2}$ & $F(35,957)$ & ISIC\# & $R^{2}$ & $F(35,957)$ \\
\hline 311 & .334 & $13.7^{* *}$ & 354 & .544 & $32.6^{* *}$ \\
312 & .019 & 0.498 & 355 & .283 & $10.8^{* *}$ \\
313 & .336 & $13.8^{* *}$ & 356 & .013 & 0.383 \\
314 & .323 & $13.0^{* *}$ & 361 & .220 & $7.7^{* *}$ \\
321 & .195 & $6.6^{* *}$ & 362 & .302 & $11.8^{* *}$ \\
322 & .515 & $28.5^{* *}$ & 369 & .283 & $10.8^{* *}$ \\
323 & .538 & $31.8^{* *}$ & 371 & .491 & $26.3^{* *}$ \\
324 & .515 & $29.0^{* *}$ & 372 & .544 & $32.6^{* *}$ \\
331 & .197 & $5.87^{* *}$ & 381 & .389 & $17.4^{* *}$ \\
332 & .266 & $9.89^{* *}$ & 382 & .331 & $13.5^{* *}$ \\
341 & .592 & $39.6^{* *}$ & 383 & .174 & $5.75^{* *}$ \\
342 & .454 & $22.7^{* *}$ & 384 & .063 & $1.83^{* *}$ \\
351 & .505 & $27.8^{* *}$ & 385 & .254 & $9.29^{* *}$ \\
352 & .011 & 0.331 & 390 & .017 & 0.472 \\
353 & .605 & $41.8^{* *}$ & & & \\
\hline
\end{tabular}

$* * \equiv$ significant at the .05 level, $F(35,957)=1.43$.

Unlike the Heckscher-Ohlin net trade equations, the dependent variable in these bilateral equations will never be negative, but they will occasionally be zero. As most of the twenty-nine equations to be estimated will contain some zero observations, equations $\left(17^{\prime}\right)$ and $\left(18^{\prime}\right)$ can be specified as a Tobit model. ${ }^{12}$

Some of the results of estimating equation (17') using the $a_{s k}$ obtained from estimating equation (18) and excluding the East Asian economies from the sample are presented in tables 3.3 and 3.4. As can be seen in table 3.3, twentysix out of the twenty-nine bilateral trade equations are statistically significant. These results mean it is possible to get a good explanation of the structure of bilateral trade when full advantage of the many available degrees of freedom is taken by including a large number of cross-country factor-endowment interaction terms. Table 3.4 identifies the statistically significant role played by the interaction between exporter and importer factor endowments in explaining bilateral trade flows. The signs of these coefficients will reflect the degree of complementarity or substitutability between the various factors of production and their relative importance in the various sectoral production processes.

are treated as proportional to the weighted average of country distance from potential trading partners. Countries are weighted in this calculation by their GNPs or GDPs. This particular approach allows the incorporation of transport costs within the bilateral Heckscher-Ohlin framework without abandoning the possibility of factor price equalization up to some multiplicative constant.

12. The Tobit estimation methods used here for equations $\left(17^{\prime}\right)$ and $\left(18^{\prime}\right)$ are described in Greene (1981, 1983) and Chung and Goldberger (1984). 
Number and Sign of Significant (.05) Coefficients on Factor-

Endowment Interaction Terms $\left(B_{j s r}\right)$

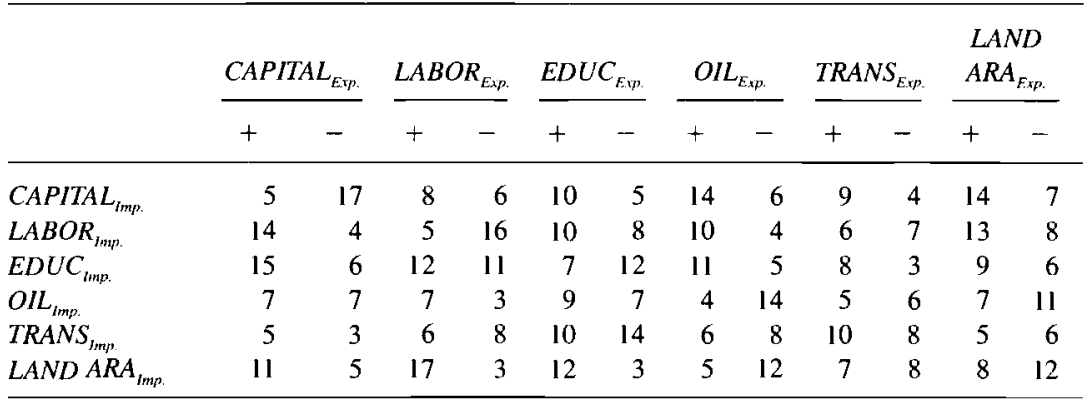

Note: The rows in this table index the factor endowments of importers. The columns index the factor endowments of exports. The cells in this table indicate how many significant coefficients of each sign are found for the associated interaction terms in the twenty-nine estimated equations.

\subsubsection{Is There Regional Bias in East Asian Trade?}

The results presented in tables 3.3 and 3.4 have been obtained by estimating equation $\left(18^{\prime}\right)$ without using East Asian observations. Using these estimated structures and introducing observations on East Asian factor endowments, tolerance intervals have been constructed for East Asian regional trade and for the major flows in East Asia's extraregional trade. The constructed tolerance intervals indicate with a probability of .99 that .99 of the normal distribution of a trade flow will be found within the interval. Observed trade flows are then compared with these tolerance intervals. Observations that fall outside these tolerance intervals are considered evidence of regional bias (Christ 1966).

The findings for East Asian intraregional exports compared with East Asian exports to much of North America and the European Community are striking. East Asian intraregional exports appear to be well-explained by the factorendowment-based gravity equations. As seen in table 3.5 , out of a total of 2,088 trade flows only 325 are outside the tolerance interval. This relatively small number of extreme observations suggests there may be little regional bias in East Asian trade. Neither policy initiatives by the Association of Southeast Asian Nations (ASEAN) nor very large intraregional East Asian investment has resulted in intraregional distortions in East Asian trade patterns. What is true for the region as a whole is also true at the individual country level. Japan, South Korea, Taiwan, Hong Kong, Malaysia, the Philippines, Singapore, Thailand, and Indonesia have no more than a small number of extreme observations on their intraregional bilateral trade flows.

By comparison with intraregional trade, East Asia's extraregional trade is marked by many observations that fall outside the constructed tolerance intervals. Whereas there are an average of thirty-nine extreme observations per in- 
Table 3.5

Extreme Observations on East Asian Intraregional Exports

\begin{tabular}{|c|c|c|c|c|c|c|c|c|c|c|c|c|c|c|c|c|c|c|}
\hline & \multicolumn{2}{|c|}{ Japan } & \multicolumn{2}{|c|}{ Korea } & \multicolumn{2}{|c|}{ Taiwan } & \multicolumn{2}{|c|}{$\begin{array}{l}\text { Hong } \\
\text { Kong }\end{array}$} & \multicolumn{2}{|c|}{ Malaysia } & \multicolumn{2}{|c|}{ Philippines } & \multicolumn{2}{|c|}{ Singapore } & \multicolumn{2}{|c|}{ Thailand } & \multicolumn{2}{|c|}{ Indonesia } \\
\hline & + & - & + & - & + & - & + & - & + & - & + & - & + & - & + & - & + & - \\
\hline Japan & 0 & 0 & 1 & 2 & 1 & 1 & 1 & 0 & 0 & 3 & 2 & 5 & 3 & 1 & 3 & 0 & 0 & 1 \\
\hline Korea & 2 & 3 & 0 & 0 & 2 & 1 & 0 & 0 & 4 & 1 & 3 & 3 & 0 & 2 & 2 & 2 & 3 & 1 \\
\hline Taiwan & 1 & 2 & 0 & 4 & 0 & 0 & 4 & 0 & 3 & 4 & 2 & 2 & 2 & 3 & 1 & 1 & 4 & 2 \\
\hline Hong Kong & 3 & 0 & 3 & 3 & 5 & 3 & 0 & 0 & 4 & 2 & l & 0 & 3 & $\mathbf{l}$ & 2 & 3 & 1 & 3 \\
\hline Malaysia & 2 & l & 0 & 2 & 2 & 1 & l & 2 & 0 & 0 & 3 & 3 & 3 & 2 & $\mathbf{l}$ & 4 & 3 & l \\
\hline Philippines & 2 & 2 & 4 & 1 & 2 & 0 & 3 & 5 & 3 & 1 & 0 & 0 & 3 & 0 & 4 & 5 & 0 & 2 \\
\hline Singapore & 0 & 5 & 1 & 0 & 1 & 4 & 2 & 4 & 4 & 3 & 3 & 2 & 0 & 0 & 2 & 3 & 5 & 1 \\
\hline Thailand & 3 & 1 & 2 & 6 & 3 & 1 & 3 & 5 & 2 & 1 & 2 & 4 & 5 & 4 & 0 & 0 & 4 & 0 \\
\hline Indonesia & 3 & 2 & 2 & 0 & 4 & 0 & 3 & 4 & 0 & 7 & 3 & 0 & 6 & 2 & 5 & 3 & 0 & 0 \\
\hline
\end{tabular}

Note: Rows in this table index imports. Columns index exports. Each cell indicates the number of extreme observations, + indicates overexporting and - underexporting. Maximum number of extreme observations for any bilateral pair is twenty-nine. Critical value for tolerance interval $T(.99, .99,957)=2.51$. 
traregional market, as seen from table 3.6 for East Asian extraregional export markets there are more than twice as many extreme observations per market. The factor-endowment-based gravity equations estimated without East Asian data do a much better job of explaining the trade among East Asian economies and overall East Asian trade, than of explaining the pattern of East Asian trade with non-East Asian trading partners.

The extraregional biases in East Asian trade are striking. Particularly interesting are the patterns of East Asian exports to the European Community by comparison with East Asian exports to North America. In some 332 instances East Asian exports to the European Community appear lower than what might have been expected, given the economic characteristics of the various East Asian economies. In each of these cases actual East Asian exports to the European Community are below the lower limit of the tolerance interval. In only a comparatively few (forty-eight) cases are actual East Asian exports to European Community markets above the upper limit of the tolerance interval. Despite very rapid growth in East Asian exports to the European Community over the past two decades, still greater exports might have been expected.

As with East Asian exports to the European Community, there are also a comparatively large number of extreme observations on East Asian exports to North America. By marked contrast with the extreme observations on East Asian exports to the European Community, the extreme observations on exports to North America are disproportionately above the upper limit of the tolerance interval. While 85 percent of the 380 extreme observations of exports to the European Community are below the lower limit of the tolerance interval, only 19 percent of the 195 extreme observations of exports to North America are below the lower limit of the tolerance interval. If East Asian exports are less to the European Community than might be expected on the basis of global relationships, they appear to be more to North America than might be expected. While there is no intraregional trade bias if East Asia is defined as a region, if the region is expanded to include the Pacific Basin, then intraregional bias does become apparent.

Does Japan play a special role in East Asia? Japan's level of productivity and its industrial skills and experience remain well ahead of even the most rapidly growing economies elsewhere in East Asia. It's hardly surprising that Japan is exporting sophisticated capital goods to its East Asian trading partners, at the same time that it's importing processed raw materials, components, and manufactures from them. There is at present little evidence of a regional bias in Japan's relations with the rest of East Asia that goes beyond the existing pattern of East Asian resource endowments. Out of 464 instances of bilateral trade flows between Japan and the other East Asian economies, only 56 extreme observations have been uncovered. These divide neatly into 16 cases of Japan overexporting, 16 cases of Japan underexporting, 11 cases of Japan overimporting, 13 cases of Japan underimporting.

What is particularly interesting about the regional pattern of Japanese trade 


\begin{tabular}{|c|c|c|c|c|c|c|c|c|c|c|c|c|c|c|c|c|c|c|}
\hline & \multicolumn{2}{|c|}{ Japan } & \multicolumn{2}{|c|}{ Korea } & \multicolumn{2}{|c|}{ Taiwan } & \multicolumn{2}{|c|}{$\begin{array}{l}\text { Hong } \\
\text { Kong }\end{array}$} & \multicolumn{2}{|c|}{ Malaysia } & \multicolumn{2}{|c|}{ Philippines } & \multicolumn{2}{|c|}{ Singapore } & \multicolumn{2}{|c|}{ Thailand } & \multicolumn{2}{|c|}{ Indonesia } \\
\hline & + & - & + & - & + & - & + & - & + & - & + & - & + & - & + & - & + & - \\
\hline United States & 9 & 3 & 11 & 4 & 14 & 6 & 8 & 1 & 12 & 3 & 6 & 0 & 12 & 3 & 7 & 2 & 4 & 1 \\
\hline Canada & 11 & 2 & 9 & 4 & 11 & 3 & 12 & 0 & 7 & 1 & 4 & 0 & 9 & 0 & 6 & 0 & 5 & 4 \\
\hline Germany & 0 & 8 & 2 & 12 & 3 & 7 & 4 & 14 & 4 & 10 & 2 & 4 & 2 & 11 & 4 & 6 & 2 & 3 \\
\hline Netherlands & 1 & 6 & 0 & 4 & 0 & 3 & 2 & 6 & 2 & 7 & 1 & 3 & 1 & 8 & 0 & 2 & 0 & 4 \\
\hline United Kingdom & 0 & 3 & 2 & 5 & 0 & 4 & 3 & 7 & 1 & 4 & 0 & 5 & 2 & 5 & 0 & 3 & 0 & 6 \\
\hline France & 0 & 7 & 0 & 8 & 2 & 10 & 1 & 11 & 0 & 8 & 2 & 7 & 0 & 13 & 2 & 8 & 3 & 8 \\
\hline Italy & 1 & 13 & 0 & 10 & 1 & 9 & 0 & 13 & 0 & 14 & 0 & 5 & 0 & 11 & 0 & 10 & 0 & 6 \\
\hline
\end{tabular}

Note: Rows in this table index imports. Columns index exports. Each cell indicates the number of extreme observations; + indicates overexporting and - underexporting. Maximum number of extreme observations for any bilateral pair is twenty-nine. Critical value for tolerance interval $T(.99, .99,957)=2.51$. 
is not how it differs from the rest of the countries in East Asia but rather how it is similar. In common with the rest of the economies, in East Asia, Japan exports less to the European Community and more to the United States than might be expected. While the European Community appears to exhibit some negative bias against imports from East Asia and overall North America appears to exhibit considerable bias in favor, Japanese import behavior, at least insofar as the model estimated here is concerned, appears virtually neutral with respect to the rest of East Asia.

\subsection{Pricing Strategies in East Asia}

If there is no special intraregional bias in East Asian trade patterns and if the growth in East Asian intraregional trade merely reflects the growing global economic importance of East Asia, are regional initiatives superfluous except as a tactical exercise to prevent discrimination and exclusion elsewhere? Not necessarily. The absence of regional bias does not necessarily mean the absence of regional trade barriers. The estimated parameters of equation $\left(18^{\prime}\right)$ may embody all manner of protective barriers. The absence of intraregional bias simply means there is no special discrimination in favor of or against East Asian trading partners (Saxonhouse 1983). This is quite a different matter from concluding, for example, that commodity arbitrage across East Asia is near perfect. How integrated are East Asian markets? One helpful way to examine this issue might be to look at East Asian firms' pricing behavior across different East Asian markets. If East Asian economies are not closely integrated with one another, East Asian firms may have greater latitude to employ widely different pricing strategies in different markets.

\subsubsection{Lags in External Adjustment}

The slow pace of adjustment to exchange rate realignment in the mid- and late 1980 s resembled the reaction of trade flows to exchange rate realignments of the early and late 1970s. In both cases special emphasis has been placed on contractual obligations and habit persistence in explaining both the slow response of prices to exchange rate changes and the slow response of trade flows to the relative price changes that do take place (Magee 1973; Wilson and Takacs 1980). In something of a departure from earlier analyses of the impact of exchange rate change on trade flows, in recent years considerable emphasis has been placed on the role of market structure in shaping this process. This new approach suggests that, in any given sector, whether exchange rate changes lead to large relative price changes or negligible price changes will depend on industrial structure considerations such as the degree of market concentration, the extent of product homogeneity and substitutability, and the relative market shares of domestic and foreign firms (Krugman 1986; Dornbusch 1987). Even absent long-term contracts and habitual behavior, strategic behavior will indicate widely varying price responses across industries to exchange 
rate changes. Less than full pass-through will be an equilibrium response for many industries.

\subsubsection{Pricing Strategies and the Pacific Adjustment Process}

In pursuing questions about the Pacific adjustment process, work that stresses the role of market structure in understanding global pricing will be helpful. Whereas most of this literature emphasizes the distinction between pricing decisions in the home market on the one hand and all overseas markets collectively on the other, the empirical research presented here will make some effort to allow for differences in pricing strategies employed across overseas markets. ${ }^{13}$ Bear in mind that different pricing strategies across markets are only possible where barriers to arbitrage exist.

\section{The International Price Discrimination Model ${ }^{14}$}

Assume that commodity arbitrage across markets is ineffective such that

$$
P_{k}^{j} \neq r_{i} P_{i}^{j}
$$

where $P_{k}^{j} \equiv$ price of good $j$ in home market $k$ in home currency; $P_{i}^{j} \equiv$ price of good $j$ in foreign market $i$ in foreign currency; and $r_{i} \equiv$ exchange rate between home currency and foreign market $i$ currency.

In general, the differences in prices across markets will be determined by the differences in demand conditions across markets and their relationship to the producer's common marginal cost. As is well known, the gap between price in each of the markets (expressed in domestic currency) and the marginal cost will be given by

$$
G_{k}^{j}=\frac{D_{k}^{j}}{D_{k}^{j}-1}, \quad \text { and } \quad G_{i}^{j}=\frac{D_{i}^{j}}{D_{i}^{j}-1},
$$

where $D_{k}^{j} \equiv$ price elasticity of demand for good $j$ in the home market $k$, and $D_{i}^{j} \equiv$ price elasticity of demand for good $j$ in the foreign market $i$.

Full pass-through. If the demand functions in domestic and overseas markets have constant price elasticities, relative prices for good $j$ across markets will be invariant. This means exchange rate changes will have no impact on relative prices. With constant price elasticity of demand curves, exchange rate changes will always be fully passed through to foreign markets.

Less than full pass-through. Less than full pass-through of exchange rate changes will occur when demand curves are less convex than the constant elasticity of demand curve. In such cases the elasticity of demand will vary directly

13. Recent papers that disaggregate among overseas markets include Froot and Klemperer (1989) and Knetter (1992, forthcoming).

14. See Krugman 1986; Dornbusch 1987; Marston 1990; Feenstra 1989. 
with price changes. In particular, a fall in price will lower price elasticity and a rise in price will raise it. From equation (20) it is seen that in this instance a fall (rise) in price will raise (lower) the gap between price and marginal cost.

Under these demand conditions when the yen appreciates, the price of the good in foreign markets rises and the gap between foreign prices and marginal cost must narrow. If marginal costs are constant, the gap between price and marginal cost will remain the same in the domestic market. This is an obvious case of less than complete pass-through.

In this case pass-through will vary across markets inversely with the convexity of the demand functions in price. Alternatively, the more elasticity of demands varies directly with price, the less pass-through will be observed.

Greater than full pass-through. By contrast with the case just described, when demand functions are more convex than the constant elasticity of price case, exchange rate changes will lead to greater than full pass-through (Marston 1990; Knetter 1992). In this case a price increase will make demand less elastic. For example, a yen appreciation by raising the foreign price of a good will increase the gap abroad between price and marginal cost. Once again with constant marginal costs, the gap between price and costs at home will remain the same. With yen appreciation, prices in terms of yen for goods abroad will rise relative to the yen price of the same goods at home. In this simple case yen appreciation may lead to a rush to concede markets abroad in the interest of profits.

Cost factors. Just as differences in the shape of demand functions are critical for explaining differences in the reactions of foreign markets to exchange rate changes, in this price discrimination framework they are also critical for explaining the influence of other factors on the differences between prices at home and abroad for the same good. For example, in the constant elasticity of demand case, since price is invariant to any kind of change, no change in wages or any other cost factor can change price, so relative prices at home and abroad will not change. More generally, if the demand functions have variable elasticities but have the same curvature, a change in cost will change prices, but always by the same rate in all markets.

In light of the above discussion and considering that income in domestic and foreign markets can be expected to affect relative prices at home and abroad, the following function can be adopted as an explanation of the gap between the domestic price of good $j$ and its price in foreign markets $i$ :

$$
\log \delta_{j}=\log \frac{P_{k}^{j}}{r_{i} P_{i}^{j}}=\rho_{1 k} \log q_{k i}+\rho_{2 k} \log \frac{w_{k}}{p_{k}}+\rho_{3 k} \log \frac{m_{k}}{p_{k}}+\rho_{4 k} \log y_{k}+\rho_{5 k} \log y_{i},
$$

where $q_{k i} \equiv$ real exchange rate between economy $k$ and economy $i, w_{k} / p_{k} \equiv$ real wages in economy $k, m_{k} / p_{k} \equiv$ real raw material prices in economy $k, y_{k} \equiv$ real income in economy $k$, and $y_{i} \equiv$ real income in economy $i$. 
Note equation (21) assumes firms set prices instantaneously in response to changes in the right-hand-side variables. If prices are preset, however, variations in $\delta_{j}$ may simply reflect unanticipated events such as change in the exchange rate, rather than destination specific price strategies.

To allow for this possibility and following Marston (1990) and Meese and Rogoff (1988), it is assumed that both $r_{i}$ and $q_{k i}$ follow random walks. This means equation (21), with time subscripted by $t$, becomes

$$
\begin{aligned}
\log \delta_{j t} & =\log \left(r_{i t}-E_{t-1} \log r_{t t}\right)+\rho_{1 k} E_{t-1} \log q_{k i t}+\rho_{2 k} E_{t-1} \log \frac{w_{k k t}^{-k t}}{p_{k t}} \\
& +\rho_{3 k} E_{t-1} \log \frac{m_{k t}}{p_{k t}}+\rho_{4 k} E_{t-1} \log y_{k t}+\rho_{5 k} E_{t-1} \log y_{i t}
\end{aligned}
$$

where $E_{t-1} \equiv$ expectation on variable in period $t$ from information available at $t-1$.

Equation (22) indicates that, if no strategic pricing behavior is being employed and the $\rho_{k}=0$, then the impact of exchange rate surprises on $\delta_{j r}$ will be short-lived. In the absence of further changes after a single period, $\delta_{j l}$ will return to its original level. Equation (22) is estimated to throw light on the role of the price mechanism in the Pacific adjustment process. The coefficient on the change in nominal exchange rate in equation (22) indicates whether there is a lag in price setting. Recall the coefficient on the real exchange rate measures the proportion of the real exchange rate change passed through into prices.

\section{Data}

Ideally, equation (22) should be estimated for exports based in each of the East Asian economies. Currently, comprehensive data are only available for exporters based in Japan. Table 3.7 lists the forty-seven product lines for which equation (22) has been estimated. Each of these forty-seven product-line equations have been separately estimated for each of the six markets, including South Korea, Taiwan, Hong Kong, Singapore, Malaysia, and Thailand.

Within the much larger number of capital goods exports, these products have been chosen on the basis of data availability for all countries in the sample. Monthly data are used for each of the countries from June 1984 to December 1989. For each of the product lines, the Bank of Japan's wholesale price index for that product is used as the Japanese domestic price. In place of detailed country-specific compatible export price data, unit value indexes have been constructed for each product line and each country from the Japan Tariff Association trade data. Admittedly, making use of bilateral unit value indexes for relatively narrow specific product lines in place of authentic price data may introduce a great deal of error into this estimation procedure. Nonetheless, because it is a relative price equation and not an import demand or export supply equation that is being estimated, the problems posed by using such data 
Table 3.7 Japanese Capital Goods Exports to East Asia (sample)

\begin{tabular}{lll}
\hline Excavators & Milling cutters & Conveyors \\
Graders & Electric welding machinery & Forklift trucks \\
Construction tractors & Rectifiers & Ball bearings \\
Shovel trucks & Magnetic switches & Roller bearings \\
Lathes & Diamond tools & Speed changers \\
NC lathes & Pneumatic tools & Roller chains \\
Drilling machines & Electric machinery tools & Copying machines \\
Boring machinery & Spinning machines & Refrigerating machines \\
NC milling machinery & Knitting machines & Woodworking machinery \\
Grinding machinery & Pumps for liquid & Printing machinery \\
NC electric discharge machinery & Air and gas compressors & Centrifugal machinery \\
Machining centers & Blowers & Electric generators \\
Press machines & Elevators & Elecric motors \\
Forging machines & Escalators & Transformers \\
Rollers for metal industry & Overhead traveling cranes & Switchboards \\
Drills & Winches & \\
\hline
\end{tabular}

Note: $N C=$ numerically controlled.

are not insurmountable. After all, this variable appears only on the left-hand side of all the equations being estimated here. ${ }^{15}$

The one truly non-Japanese source of data in this estimation is the monthly production indexes used as the active variable in equation (22). These indexes have been gathered from the monthly or yearly statistical bulletins of each of the six countries in this sample as well as from Japan. The remaining variables, including the Japanese manufacturing wage, Japanese raw material prices, and the bilateral exchange rates, are all readily available. Finally, in each instance, nominal variables are converted to real variables by deflating with the Japanese wholesale price index.

\section{Estimation}

Two hundred and eighty-two relative price equations have been estimated with the data just outlined. Each equation is estimated with seventy-seven observations after logarithms of each variable have been first differenced and distributed lags applied. The general results of this estimation are presented in tables 3.8 and 3.9 .

As indicated, interest should focus on the coefficients of the change in the nominal exchange rate and the coefficients on the level of the real exchange rate. No less than 201 cases out of a possible total of 282 coefficients on the level of the real exchange rate are statistically significant from zero.

At the level of the individual foreign market level, these results confirm findings from many studies for aggregated overseas markets. Strategic pricing

15. Froot and Klemperer (1989) and Knetter (forthcoming) follow a similar path in constructing destination-specific export price data. 
Table 3.8

Foreign Price-Domestic Price Gap Equation: Statistically Significant Variables by Country ( 47 equations estimated for each country)

\begin{tabular}{lcccccc}
\hline & Korea & Taiwan & Hong Kong & Singapore & Malaysia & Thailand \\
\hline $\begin{array}{l}\text { Statistically significant price } \\
\quad \text { selling lag }\end{array}$ & 12 & 10 & 12 & 8 & 20 & 15 \\
$\begin{array}{l}\text { Statistically significant } \\
\quad \text { strategic price setting due }\end{array}$ & & & & & & \\
$\quad$ to real exchange rate & & & & & & \\
$\quad$ change $H_{0}: \rho_{1}=0$ & 45 & 39 & 32 & 25 & 32 & 33 \\
Satistically significant & & & & & & \\
$\quad$ strategic price setting due & & & & & & \\
$\quad$ to changes in other & & & & & & \\
$\quad$ variables $H_{0}: \rho_{2}=0 ;$ & 17 & 18 & 10 & 7 & 12 & 8 \\
$\quad \rho_{3}=0 ; \rho_{4}=0 ; \rho_{5}=0$ & 6 & 7 & 4 & 6 & 8 & 9 \\
$R^{2}=.000-.333$ & 16 & 14 & 14 & 11 & 12 & 13 \\
$R^{2}=.334-.666$ & 25 & 26 & 29 & 30 & 27 & 25 \\
$R^{2}=.666-.991$ & & & & & & \\
\hline
\end{tabular}

Note: The numbers in each cell refer to the number of equations in which a statistically significant variable corresponding to the row heading appeared. Forty-seven is the maximum number of equations in which a variable can appear as statistically significant.

is a pervasive phenomenon. Of particular interest here, Japanese exporters exhibit this behavior in the majority of their Pacific markets. Such behavior is most pronounced in the Korean market and is practiced by Japanese machinery exporters for the vast majority of the capital goods they sell in East Asia. Among types of machinery exports, machinery components, for whatever reason, seem less subject to strategic pricing than the complete machine.

Not all 201 statistically significant coefficients on the real exchange rate are positive. In no less than twenty cases here this coefficient is negative, illustrating the case where rate changes are more than passed through into foreign prices. The distribution of such cases by country is given in table 3.10. These cases typically reflect the very small size of some of the overseas markets being investigated here and the resulting instability of some of the unit value indexes being used as dependent variables.

While strategic pricing is a pervasive phenomenon among Japanese machinery exporters to elsewhere in East Asia, tables 3.8 and 3.9 indicate that this is almost exclusively a response to exchange rate changes. In only 72 out of a possible 1,126 cases is there any indication that the gap between foreign prices and domestic prices adjusts in a statistically significant way as a response to changes in domestic costs or to shifts in income in either foreign or domestic markets. ${ }^{16}$ Given the extreme volatility of the real exchange rate compared with these other variables, this result should not be surprising.

More surprising are the relatively few instances where there are significant 
Table 3.9

Foreign Price-Domestic Price Gap Equation: Statistically Significant Variables by Capital Good

\begin{tabular}{|c|c|c|c|}
\hline Market & $\begin{array}{c}\text { Statistically } \\
\text { Significant } \\
\text { Price Setting } \\
\text { Lag }\end{array}$ & $\begin{array}{c}\text { Statistically } \\
\text { Significant } \\
\text { Strategic Price } \\
\text { Setting due to } \\
\text { Real Exchange } \\
\text { Change } \\
H_{0}: \rho_{1}=0\end{array}$ & $\begin{array}{l}\text { Statistically } \\
\text { Significant } \\
\text { Strategic Price } \\
\text { Setting due to } \\
\text { Changes in } \\
\text { Other Variables }\end{array}$ \\
\hline Excavators & 2 & 3 & - \\
\hline Graders & 1 & 2 & 2 \\
\hline Construction tractors & 3 & 5 & 1 \\
\hline Shovel trucks & 1 & 3 & 3 \\
\hline Lathes & 4 & 3 & 4 \\
\hline NC lathes & 3 & 5 & 2 \\
\hline Drilling machines & 3 & 3 & - \\
\hline Boring machinery & - & 6 & 1 \\
\hline NC milling machinery & 1 & 6 & - \\
\hline Grinding machinery & 1 & 5 & - \\
\hline $\mathrm{NC}$ electric discharge machinery & 1 & 4 & 2 \\
\hline Machining centers & - & 6 & - \\
\hline Press machines & 1 & 1 & 1 \\
\hline Forging machines & - & 4 & 1 \\
\hline Rollers for metal industry & 4 & 5 & 4 \\
\hline Drills & 2 & 5 & 2 \\
\hline Milling cutters & 1 & 6 & - \\
\hline Electric welding machine & 1 & 3 & - \\
\hline Rectifiers & 3 & 5 & 3 \\
\hline Magnetic switches & 3 & 5 & 1 \\
\hline Diamond tools & 2 & 3 & 2 \\
\hline Pneumatic tools & 4 & 4 & 2 \\
\hline Electric machinery tools & 1 & 6 & 1 \\
\hline Spinning machines & - & 6 & - \\
\hline Knitting machines & 1 & 6 & - \\
\hline Pumps for liquid & 3 & 6 & 5 \\
\hline Air and gas compressors & 4 & 5 & 3 \\
\hline Blowers & 3 & 3 & 4 \\
\hline Elevators & 2 & 6 & 2 \\
\hline Escalators & 5 & 5 & 2 \\
\hline Overhead traveling cranes & - & 6 & - \\
\hline Winches & 3 & 4 & 3 \\
\hline Conveyors & 2 & 4 & 4 \\
\hline Forklift trucks & - & 6 & 3 \\
\hline Ball bearings & 5 & 5 & - \\
\hline Roller bearings & 2 & 4 & 3 \\
\hline Speed changers & 2 & 2 & 1 \\
\hline Roller chains & 2 & 1 & 2 \\
\hline Copying machines & - & 4 & 2 \\
\hline Refrigerating machines & - & 5 & 2 \\
\hline Woodworking machinery & - & 6 & - \\
\hline
\end{tabular}




\begin{tabular}{|c|c|c|c|}
\hline Market & $\begin{array}{c}\text { Statistically } \\
\text { Significant } \\
\text { Price Setting } \\
\text { Lag }\end{array}$ & $\begin{array}{c}\text { Statistically } \\
\text { Significant } \\
\text { Strategic Price } \\
\text { Setting due to } \\
\text { Real Exchange } \\
\text { Change } \\
H_{0}: \rho_{1}=0\end{array}$ & $\begin{array}{c}\text { Statistically } \\
\text { Significant } \\
\text { Strategic Price } \\
\text { Setting due to } \\
\text { Changes in } \\
\text { Other Variables }\end{array}$ \\
\hline Printing machinery & - & 6 & 2 \\
\hline Centrifugal machinery & - & 4 & - \\
\hline Electric generators & - & 6 & 1 \\
\hline Electric motors & 1 & 4 & - \\
\hline Transformers & 4 & 4 & 1 \\
\hline Switchboards & - & 6 & - \\
\hline
\end{tabular}

Notes: Coefficients here are statistically significant at the .05 level.

Table 3.10 Cases of More than Full Pass-Through by Country

\begin{tabular}{lclll}
\hline Korea & 2 & Singapore & 5 \\
Taiwan & - & Malaysia & 3 \\
Hong Kong & 4 & Thailand & 6 \\
\hline
\end{tabular}

lags in the resulting prices after exchange rate changes unaccompanied by strategic price behavior. Overall, there are seventy-seven cases where the coefficient on the change in the nominal exchange rate variable is statistically significant. In only twenty-eight of these cases, however, are $\rho_{k}=0$ and the lags in resetting export prices solely responsible for the change in the gap between export prices and home market prices.

What is particularly interesting here is not just that Japanese firms practice strategic price setting in all their East Asian markets for almost all the capital goods in this sample. This simply tells us that the Japanese market is not fully integrated with the rest of East Asia. What is of special importance here is the degree to which strategic price setting by Japanese firms varies across East Asian markets. As seen in table 3.11, in no less than thirty-seven out of fortyseven product lines, the hypothesis cannot be accepted that the coefficient on the real exchange rate is the same across East Asian markets. Significant barriers to commodity arbitrage in East Asia appear to exist. Considering the interest in regional trade and investment initiatives in East Asia, further investigation is clearly needed as to why pricing behavior by exporters of the same machinery should vary so much across geographical markets. Do Japanese firms really have the capacity to effectively segregate proximate markets in the absence of host government connivance of some sort?

The results on the weakness of commodity arbitrage rest on a very simple model of international price discrimination. The limitation of this model 
Table 3.11

Do Japanese Firms Use Different Price Strategies across East Asian Markets?

\begin{tabular}{lclc}
\hline & $F(6,432)$ & & $F(6,432)$ \\
\hline Excavators & 3.5 & Knitting machines & $11.4^{*}$ \\
Graders & 4.3 & Pumps for liquids & 0.6 \\
Construction tractors & $12.5^{*}$ & Air and gas compressors & $45.6^{*}$ \\
Shovel trucks & $6.8^{*}$ & Blowers & 3.1 \\
Lathes & $22.5^{*}$ & Elevators & $11.4^{*}$ \\
NC lathes & $15.9^{*}$ & Escalators & $8.2^{*}$ \\
Drilling machines & $41.0^{*}$ & Overhead traveling cranes & $7.0^{*}$ \\
Boring machinery & $23.6^{*}$ & Winches & $19.7^{*}$ \\
NC milling machinery & $7.4^{*}$ & Conveyors & $53.5^{*}$ \\
Grinding machinery & $8.2^{*}$ & Forklift trucks & $7.6^{*}$ \\
NC electric discharge machinery & $8.5^{*}$ & Ball bearings & $17.6^{*}$ \\
Machining centers & $6.8^{*}$ & Roller bearings & $23.2^{*}$ \\
Press machines & 4.3 & Speed changers & 2.3 \\
Forging machines & $6.8^{*}$ & Roller chains & 3.6 \\
Rollers for metal industry & $7.1^{*}$ & Copying machines & $8.3^{*}$ \\
Drills & $11.6^{*}$ & Refrigerating machines & $6.5^{*}$ \\
Milling cutters & $9.8^{*}$ & Woodworking machinery & $7.9^{*}$ \\
Electric welding machinery & 1.4 & Printing machinery & $9.4^{*}$ \\
Rectifiers & $26.1^{*}$ & Centrifugal machinery & $11.5^{*}$ \\
Magnetic switches & $12.8^{*}$ & Electric generators & $17.0^{*}$ \\
Diamond tools & 2.7 & Electric motors & $34.5^{*}$ \\
Pneumatic tools & $29.3^{*}$ & Transformers & $21.5^{*}$ \\
Electric machinery tools & $6.7^{*}$ & Switchboards & $8.3^{*}$ \\
Spinning machines & 4.8 & & \\
\hline
\end{tabular}

Notes: Following Leamer $(1978),{ }^{*} \equiv F(6,432)>5.88$ is chosen as the criterion for statistical significance. $H_{0}: \rho_{1 \text { Korea }}=\rho_{1 \text { Taiwan }}=\rho_{1 \text { Hong Kong }}=\rho_{1 \text { Singapore }}=\rho_{\text {IMalaysia }}=\rho_{1 \text { Thailand }}$

should not be forgotten (see Knetter 1992). Even apart from issues of specification, further evidence for other product lines and for firms based in other East Asian home markets needs to be examined. Despite the extraordinary growth in intraregional trade in East Asia, the price evidence presented here suggests the continuing importance of official and nonofficial barriers to intraregional trade in East Asia. Are these barriers, however, significantly different from barriers to intraregional trade in North America or Western Europe? The results of estimating equation (22) for Japanese firm behavior in the U.S. and Canadian markets for forty-three capital goods are presented in table 3.12. Surprisingly, in less than half the cases in either the U.S. or the Canadian market is the real exchange rate coefficient statistically significant. Despite all the complaints about lack of Japanese pass-through of exchange rate changes in the North American market, strategic pricing is far less pervasive there than in East Asia. Moreover, as indicated in table 3.12, while there may be as many as twenty product lines in the sample examined here where the U.S. and Canadian markets do not appear well integrated with the rest of the global economy, in 
Table 3.12

Japanese Strategic Price Setting in North America

\begin{tabular}{|c|c|c|c|}
\hline & $\begin{array}{c}\text { Canada } \\
\rho_{\text {ICanads }}=0\end{array}$ & $\begin{array}{c}\text { United States } \\
p_{\text {Iu.s. }}=0\end{array}$ & $\begin{array}{c}F(2,152) \\
\rho_{\text {ICanada }}=\rho_{\text {ius }}\end{array}$ \\
\hline Excavators & - & - & 0.6 \\
\hline Graders & - & - & 1.2 \\
\hline Construction tractors & $*$ & $*$ & $7.3^{*}$ \\
\hline Shovel trucks & - & - & 3.5 \\
\hline Lathes & - & - & 0.1 \\
\hline NC lathes & - & $*$ & 2.7 \\
\hline Drilling machines & - & - & 2.4 \\
\hline Boring machinery & $*$ & - & 3.9 \\
\hline $\mathrm{NC}$ milling machinery & * & $*$ & $11.3^{*}$ \\
\hline Grinding machinery & $*$ & - & $5.7^{*}$ \\
\hline NC electric discharge machinery & - & $*$ & 3.9 \\
\hline Machining centers & $*$ & $*$ & $17.4^{*}$ \\
\hline Press machines & - & - & 3.0 \\
\hline Forging machines & $*$ & - & 4.7 \\
\hline Rollers for metal industry & - & $*$ & 4.3 \\
\hline Drills & $*$ & * & $6.3^{*}$ \\
\hline Milling cutters & $*$ & * & $11.4 *$ \\
\hline Electric welding machinery & - & - & 2.3 \\
\hline Rectifiers & - & $*$ & $5.8^{*}$ \\
\hline Magnetic switches & $*$ & - & 4.0 \\
\hline Diamond tools & - & - & 1.8 \\
\hline Pneumatic tools & - & $*$ & 3.6 \\
\hline Electric machinery tools & $*$ & * & 3.8 \\
\hline Pumps for liquids & $*$ & $*$ & 8.8 \\
\hline Air and gas compressors & - & - & 2.1 \\
\hline Blowers & - & - & 0.9 \\
\hline Escalators & - & $*$ & 2.5 \\
\hline Winches & - & - & 3.2 \\
\hline Conveyors & - & $*$ & 4.3 \\
\hline Forklift trucks & $*$ & $*$ & $11.8^{*}$ \\
\hline Ball bearings & $*$ & - & 3.7 \\
\hline Roller bearings & - & - & 2.9 \\
\hline Speed changers & - & - & 0.8 \\
\hline Roller chains & - & - & 0.3 \\
\hline Copying machines & $*$ & - & 4.3 \\
\hline Refrigerating machines & $*$ & $*$ & 3.9 \\
\hline Woodworking machinery & $*$ & $*$ & 3.6 \\
\hline Printing machinery & $*$ & $*$ & $8.4^{*}$ \\
\hline Centrifugal machinery & - & - & 2.2 \\
\hline Electric generators & $*$ & - & $9.3^{*}$ \\
\hline Electric motors & - & - & 3.7 \\
\hline Transformers & - & - & 1.4 \\
\hline Switchboards & $*$ & - & 3.2 \\
\hline
\end{tabular}

$* \equiv$ Statistically significant; $F(2,152)>4.797$, following significance levels correction suggested in Leamer (1978). 
only half as many cases do Japanese firms act as if commodity arbitrage is not an easy matter across the U.S.-Canadian border. By comparison with their behavior in East Asia, Japanese firms appear to treat the U.S.-Canadian markets as very well integrated. This is true even for the period before the CanadaU.S. Free Trade Agreement was ratified.

Despite the absence of intraregional bias in East Asian trade, evidence on the ability of Japanese firms to behave as if East Asian markets are substantially segregated from one another and their inability to behave the same way in North America does suggest that important barriers to East Asian trade remain. Quite apart from the tactical benefits in global negotiations that an East Asian grouping might bring, new East Asian-wide liberalization could still have substantial trade-creating effects within the region.

\subsection{Finale}

Regional initiatives in Europe and North America have triggered considerable interest and concern in the Pacific Basin. New trade initiatives by ASEAN, the Mahathir proposal for an East Asian economic group, the rapidly evolving APEC now with its own secretariat reflect, at least in part, a reaction to developments elsewhere. This is quite apart from the somewhat more familiar, smaller subregional trading zones, proposals for which are once again proliferating wherever there is proximity in East Asia. These proposals are not being made in the face of long-dormant East Asian economic interaction. Quite the contrary. In absolute terms, East Asian regional trade and East Asian crossinvestment have grown very rapidly.

In the perspective of these developments, this paper concludes

1. It is certainly possible that trading blocs being formed elsewhere in the world might lower East Asian welfare. This can happen even in the absence of any explicit or implicit effort by these blocs to exploit their market power at the expense of East Asia. These trading blocs may have no incentive to expand their membership to include East Asian economies except insofar as they fear provoking the formation of an East Asian trading bloc. In the presence of a substantial group of disorganized, nonretaliating outsiders, a trading bloc, even without violating GATT Article 24, can achieve outcomes for its members that might be superior to global free trade.

2. The rapid growth in intraregional East Asia reflects not much more than the very rapid overall growth in this region relative to the rest of the world. Estimation of a bilateral model of intraindustry trade using a factorendowment-based version of the gravity model suggests no East Asian bias in the trading pattern of the leading economies there. When the Pacific region is defined to include North America, however, substantial regional bias will likely be present. This reflects the positive bias found in East Asian exports to North America. By contrast, there is a negative bias in East Asian exports to Western Europe. 
3. Despite the absence of intraregional bias in East Asian exports, evidence on the ability of Japanese firms to behave as if East Asian markets were substantially segregated from one another and their inability to behave the same way in North America does suggest that important barriers to East Asian trade remain. Despite much recent progress, further regionwide liberalization could be of particular benefit.

\section{References}

Anderson, James E. 1979. A Theoretical Foundation for the Gravity Equation. American Economic Review 69:106-16.

Christ, Carl F. 1966. Econometric Models and Methods. New York: John Wiley.

Chung, Ching-fan, and Arthur S. Goldberger. 1984. Proportional Projections on Limited Dependent Variable Models. Econometrica 52:531-34.

Dixit, Avinash, and Victor Norman. 1980. Theory of International Trade. Cambridge: Cambridge University Press.

Dornbusch, Rudiger. 1987. Exchange Rates and Prices. American Economic Review 77:93-106.

Durbin, James. 1954. Errors in Variables. Review of the International Statistical Institute 22:23-32.

Feenstra, Robert. 1989. Symmetric Pass-through of Tariffs and Exchange Rates under Imperfect Competition: An Empirical Test. Journal of International Economics 27:25-45.

Froot, Kenneth A., and Paul D. Klemperer. 1989. Exchange Rate Pass-through When Market Share Matters. American Economic Review 79:637-54.

Greene, William H. 1981. On the Asymptotic Bias of the Ordinary Least Squares Estimation of the Tobit Model. Econometrica 49:505-13.

- 1983. Estimation of Limited Dependent Variables by Ordinary Least Squares and Method of Moments. Journal of Econometrics 21:195-212.

Guilkey, D. K., and P. Schmidt. 1973. Estimation of Seemingly Unrelated Regressions with Autoregressive Errors. Journal of the American Statistical Association 68:642-47.

Helpman, Elhanan, and Paul R. Krugman. 1985. Market Structure and Foreign Trade. Cambridge: MIT Press.

Kemp, Murray C., and Henry Y. Wan. 1976. An Elementary Proposition Concerning the Formation of Customs Unions. Journal of International Economics 6:95-97.

Knetter, Michael. 1992. Exchange Rates and Corporate Pricing Strategies. NBER Working Paper no. 415l. Cambridge: National Bureau of Economic Research.

- Forthcoming. International Comparisons of Pricing to Market Behavior. American Economic Review.

Krugman, Paul, 1986. Pricing to Market When the Exchange Rate Changes. NBER Working Paper no. 1926. Cambridge: National Bureau of Economic Research.

- Is Bilateralism Bad? In International Trade and Trade Policy, ed. Elhanan Helpman and Assaf Razin. Cambridge: MIT Press.

Leamer, Edward E. 1978. Specification Searches. New York: John Wiley. . 1984. Sources of Comparative Advantage. Cambridge: MIT Press.

Leontief, W. W. 1956. Factor Proportions and the Structure of American Trade: Further Theoretical and Empirical Analysis. Review of Economics and Statistics 38:386-407. 
Machlup, Fritz. 1977. A History of Thought on Economic Integration. New York: Columbia University Press.

Magee, Stephen P. 1973. Currency Contracts, Pass-through, and Devaluation. Brookings Papers in Economic Activity 1:303-23.

Marston, Richard C. 1990. Pricing to Market in Japanese Manufacturing. Journal of International Economics 29:217-36.

Meese, Richard, and Kenneth Rogoff. 1988. "Was It Real? The Exchange Rate-Interest Rate Differential over the Modern Floating Period. Journal of Finance 43:933-48.

Saxonhouse, Gary R. 1983. The Micro- and Macroeconomics of Foreign Sales to Japan. In Trade Policy in the 1980's, ed. W. Cline, 259--304. Cambridge: MIT Press.

. 1989. Differentiated Products, Economies of Scale, and Access to the Japanese Market. In Trade Policies for International Competitiveness, ed. Robert Feenstra, 145-74. Chicago: University of Chicago Press. 1992. Europe's Economic Relations with Japan. In Singular Europe, ed. William James Adams, 347-69. Ann Arbor: University of Michigan Press.

Saxonhouse, Gary R., and Robert M. Stern. 1989. An Analytical Survey of Formal and Informal Barriers to International Trade and Investment in the United States, Japan, and Canada. In Trade and Investment Relations among the United States, Canada, and Japan, ed. Robert M. Stern, 293-353. Chicago: University of Chicago Press.

Stoeckel, Andrew, David Pearce, and Gary Banks. 1990. Western Trading Blocs. Canberra: Center for International Economics.

Viner, J. 1950. The Customs Union 1ssue. Washington, DC: Carnegie Endowment for International Peace.

Wilson, John F., and Wendy E. Takacs. 1980. Expectations and the Adjustment of Trade Flows under Floating Exchange Rates: Leads, Lags, and J-Curve. International Finance Discussion Paper no. 160. Washington, DC: Board of Governors of the Federal Reserve System.

\section{Comment Robert Gilpin}

The theme of my comments is that institutions are important in understanding how market forces affect international affairs. As political scientists at this conference have been emphasizing, economists too frequently omit institutions just as political scientists too frequently underestimate the role and efficacy of markets in human affairs. In my comments, however, I am interested only in pointing out the limitations of economic analysis of developments in East Asia.

The world of the economist is composed primarily of individual firms and consumers responding to changes in prices and quantities. Such neoclassical methods of analysis are very powerful tools indeed, and needless to say, many political scientists envy the economists their models and equations. But it is important to recognize that market signals take place in an institutional setting. As economists since Ronald Coase have taught us, institutions can do many good and useful things, that is, decrease transactions costs, reduce uncertainties, and enhance efficiency. But as several political scientists have emphasized

Robert Gilpin is the Dwight D. Eisenhower Professor of International Affairs, Princeton University, and a faculty associate of the Center of International Studies. 
over the past few days, institutions also create differential opportunities and constraints on economic activities. Institutions do not create opportunities and constraints equally for all firms and consumers. By their very nature, institutions exclude some participants and have powerful distributive effects both domestically and internationally. In fact, as we all know but too frequently forget, institutions are created for purposes of rent seeking and redistribution perhaps as frequently as they are created to increase efficiency.

As economists have taught those of us who might be called "political economists," or as one of my Princeton economist colleagues prefers, "economical politicians," what transforms the world are major price changes, supply shocks, and the like. From this perspective the most significant transforming event in the recent history of the Pacific economy has been the dramatic appreciation of the yen (endaka) following the Plaza Accord of September 1985. Before this development, Japan had been interested in Southeast Asia, especially Malaysia and Thailand, primarily as sources of raw materials. There was relatively little Japanese foreign direct investment (FDI) in the region and almost none in the manufacturing and services sectors.

The effect of endaka was suddenly to make many Japanese products noncompetitive in world markets. In response to this development, Japanese multinational corporations, with the support of the Japanese government, began to invest heavily and to establish subsidiaries in Southeast Asia. In particular, they established overseas manufacturing subsidiaries in those low-tech industries in which Japan was losing comparative advantage because of yen appreciation. At the same time, these Japanese firms moved up the technological ladder at home to high-tech industries and exports. While these developments were a rational response to market forces, it is important to understand that they are an outgrowth of Japanese industrial organization and the relations of the Japanese corporation to the Japanese state.

Through the combination of Japanese FDI, intrafirm trade, and the infrastructure investments financed by Japanese official development assistance (ODA), the Southeast Asian economies are being linked closely to the Japanese home economy. In a number of industrial sectors such as automobiles and consumer electronics, a regional division of labor and complementary economic ties under Japanese leadership are being created. Whereas Japan is the primary producer of high-tech, high value-added products and components, the subsidiaries of Japanese firms in Southeast Asia are either assembly operations or producers of labor-intensive goods that employ lower-cost local labor. Products produced by Japanese subsidiaries in Southeast Asia are for local consumption, for export back to Japan itself, or for third markets, especially the United States. Peter Petri in his paper gives us a wonderful picture of one example of this evolving regional division of labor in what he calls Toyota Motor's regional interdependence structure. In effect, a regional institutional structure uniting Japan and the Southeast Asia economies is taking shape that will have significantly distributive effects on third countries. 
It is quite obvious that developments in East Asia have great economic and potential political significance. However, this development is not adequately captured by Gary Saxonhouse's paper. His analysis does not really address the changing economic and institutional relationships. I do not and in fact cannot challenge his economic analysis of intraregional and extraregional trade flows. His careful analysis of the data is certainly reasonable and convincing on its own terms. But one wants to know whose trade and what trade are benefiting from the increasing economic and institutional ties in the region that are being created by Japanese investment and ODA flows. For example, as has been suggested above, we know that Japanese firms control the production and trade in almost all high-tech industries such as automobiles and consumer electronics. This fact is a datum point that is as important as Saxonhouse's gross trade figures. Institutional ties really capture the economic and political significance of what is happening in the region.

It is undoubtedly true, as many participants in this conference have emphasized, that Japanese FDI, trade, and ODA are of great benefit to the region. Furthermore, I personally do not fear, at least for the moment, the reestablishment of a Japanese-led coprosperity sphere in the region. However, the overall results of the integration of vital sectors of these regional economies with the Japanese home economy does raise issues of long-term significance. These developments appear to be the following:

1. The increasing importance of the Japanese model of political economy in the economic development strategies of the economies in the region. This model has at least three elements that distinguish it from the American model of political economy: the primacy of producer over consumer interests, an industrial organization based on industrial groupings, and the crucial role of state interventionism in guiding economic development.

2. The internationalization of Japanese industrial policy, that is, the effort of Japanese firms backed by the Japanese state to create in the region a group of complementary economies and a regional division of labor.

3. The creation of a Japanese-led system of international production, especially in high-tech sectors, closely integrated with the Japanese home economy. As some commentators have suggested, it is unnecessary for Japan to create a formal regional bloc because Japanese corporations in the region are creating a de facto regional bloc.

Whether the long-term result of these developments will be an East Asian trading region within a larger multilateral global economy, an exclusive East Asian trading bloc, or a revival of the 1930s coprosperity sphere has yet to be determined. A great deal will obviously depend on what happens in North America and especially in Western Europe. Will these regional economies remain open or will they become closed systems? Japan and the other East Asian economies are highly dependent on world markets and are hardly likely to initiate moves that would encourage an intensification of regional trading ar- 
rangements. Meanwhile, several questions need to be posed. The first is whether nations with fundamentally different economic institutions will want to play by basically different rules. For example, the United States and Japan have very different concepts of antitrust and collusive behavior. Are Japanese firms establishing such an overwhelming presence in the region that nonJapanese firms will be effectively excluded? A lot of evidence suggests that this development is already occurring. Will the United States continue to provide a security umbrella over a region in which its economic interests are declining? Again, there is much evidence to suggest that such a pullback has already begun. These questions are but a few that suggest that political analysis, however intuitive it may sometimes be, is a necessary complement to the more rigorous methods of the economist.

I said earlier that economists are very sensitive to price changes and are alert to their effects. By the same token, political scientists tend to be very sensitive to changes in power relations and their effects. When one observes major shifts in the global or regional distribution of economic and hence political power, there will inevitably be profound security and diplomatic effects. For this reason, it is important to ask what these political and security consequences could be rather than to imply that nothing of political significance is occurring. In East and Southeast Asia, we must be alert to the significant shift in the distribution of economic power that is taking place and that in time will profoundly affect the security relations in the regions.

\section{Comment Lawrence B. Krause}

The excellent papers by Peter Petri, Jeffrey Frankel, and Gary Saxonhouse make a similar point in different ways, namely, that trade and other economic relations in the Pacific Basin do not reflect a line down the Pacific that separates the western Pacific from North America. Instead economic forces seem to be integrating the two sides of the Pacific into a single region.

Nevertheless, because of there being three very large industrial countries with currencies to match (German D-mark, Japanese yen, and U.S. dollar), it is commonplace for reference to be made to triad power, or even more pointedly to a three-bloc world. This literary shorthand would not be of much concern except that, if three blocs were to become a reality, it could mean a disaster for the world economy. There is little doubt that Europe is a distinct region, and that Germany is its most powerful member. However, the question remains as to whether Japan and the United States are in economically distinct regions,

Lawrence B. Krause is Pacific Economic Cooperation Professor and director of the KoreaPacific Program at the Graduate School of International Relations and Pacific Studies, University of California, San Diego. 
or whether they are part of the same economic entity. The three papers give support to the latter conception.

What would be so bad about a three-bloc world? Analysis of a three-bloc configuration with Germany, the United States, and Japan being the regional hegemonies suggest that they would be internally contentious and externally aggressive. Game theory suggests that such a trading system would be very unstable in that there would be frequent changes in alliances, regions would follow aggressive tit-for-tat strategies, and short-term considerations would overwhelm long-term interests. The most serious problems would arise if Japan and the United States were to be in different and rival regions, for these two countries represent the most extreme examples of economic integration among nonneighboring countries anywhere in the world. It is unlikely that the global system as it exists today could be sustained in such an atmosphere.

What gives the three-bloc concept some saliency is the formalization of the already existing close economic integration of North America into NAFTA, and the ill-considered trade elements in President Bush's Enterprise of the Americas Initiative (EAI), which could extend NAFTA to the whole of the Western Hemisphere. While analysis can clearly show that even an expanded NAFTA cannot replace global economic linkages for the United States, fear has been created that the United States may be turning inward within the confines of a protected subregion. This has led to suggestions for an East Asian economic group or caucus.

How can the breakup of the world economy into three rival trading regions be prevented? Would it not be better to have just a multilateral system without any regions at all? In the abstract, it might have been better if the European Community had not been a political necessity, but it was, and no one should believe that breaking up the EC today would be beneficial for any country. It should also be noted that NAFTA is desirable on its own terms and should not disadvantage nonmember countries. Canada, Mexico, and the United States are special cases of neighbors well along in the process of integration. In reality, capital markets and labor markets are already integrated. Only the goods and service markets were separated, which NAFTA is designed to correct.

Could NAFTA turn inward and cause the problems that others fear? It is probably less likely that the North American countries would collectively turn inward than they would individually. NAFTA is simply too small to serve the needs of the United States. The United States requires access to global markets and particularly the growing markets of the Pacific Basin. The United States could not confine its economic activity to North America without severe economic hardship.

If a rival East Asian bloc were to be created in the absence of any real need, it would raise concerns elsewhere as to what its real intentions were. Hence the onus of undermining the world economy would fall on East Asia, not on the EC or NAFTA (although NAFTA should not be enlarged).

With the end of the Uruguay Round of GATT negotiations, attention will 
turn to regional initiatives. The time will be ripe for solidifying an institutional structure that reflects the economic reality analyzed in the three papers. This can be done by building an APEC, which includes the United States, Japan, and the other outwardly oriented countries of the Pacific. With a strong APEC, the world trade regime would be headed toward a benign two-region world rather than a three-bloc configuration. 